\title{
Strategies of developers to housing supply within framework of project financing
}

\author{
Olga V. Grushina ${ }^{1, *}$, and Natalya N. Shelomentseva ${ }^{2}$ \\ ${ }^{1}$ Baikal State University, 11, Lenina ave., Irkutsk, Russia \\ ${ }^{2}$ Irkutsk State University, 20, Gagarin boulevard, Irkutsk, Russia
}

\begin{abstract}
The problem of providing comfortable and affordable housing for Russian citizens as a national goal has gained an impetus to solution after the introduction at the legislative level of project financing for housing construction using escrow accounts. The application of this new method of financing to the decision-making algorithm of a developer requires mathematical modeling of the economic ratios of the main indicators of the developer's activities, taking into account the interests of other subjects in the housing construction sector: banks and population. The approach proposed by the authors is aimed primarily at expanding the supply in the housing market. We have formalized the possible sale strategies of the developer using a matrix approach in varying prices and the number of meters sold at different stages of construction, as well as interest rates for bank crediting, depending on the degree of escrow accounts accumulation. Testing the model has shown that developers should face serious problems related to increasing the cost of replenishing working capital for the construction process, which will inevitably be included in the price per square meter of housing and paid by the consumer (population). At the same time, banks become the main controllers and beneficiaries of the project financing. The model developed and tested by the authors will allow construction organizations to overcome the first difficulties of project financing application and competently and consistently make a choice of a strategy for offering housing to buyers, taking into account the variability of the economic parameters of all parties.
\end{abstract}

Keywords: project financing, supply in the housing market, costs, working capital requirements, escrow accounts.

\section{Introduction}

The milestone transition from various schemes of share participation to project financing in housing construction has been widely discussed in the scientific community, especially in the last 3 years. Nevertheless, the perspectives of the project financing have been estimated earlier for some large projects in the Russian Federation, while abroad this method of financing has a wellestablished long-standing practice $[3,9,11]$.

The project financing itself can be impersonally characterized as a special way of financing "a large and viable project, which is financially and legally separated from the activities of a company, where a money lender considers the cash flows and economic income from this project as a source of credit repayment" [20]. In other words, the project financing features the separation of the construction object from the activities of the developer as an enterprise, the targeted use of credit under the control of the bank and its repayment from income obtained from the sale of this object.

The main declared goal of the project financing is to solve once and for all the problem of defrauded homebuyers with the help of not state, but banks. The latter are embedded in the hitherto short link "developerhousing equity holder" as a third actor, last but not least (last in number, but not in importance). The main consequence is that the role of banks is dramatically increasing many times over, driving out the functions of the state. According to the prophecy of R. Hilferding, financial capital becomes the ruler of people's lives [7]. Apparently, this goal is not declared. Banks that take on the risks of equity holders according to the previous scheme get the main benefits of the project. Hitherto free funds of equity holders are transformed into the borrowed moneys of the bank by a clever movement of escrow accounts.

The noble social purpose of providing citizens with affordable and comfortable housing casts a shadow on the super-profit of the financial sector and the further aggravates the crisis in the real sector of the housing construction industry. It should be emphasized that money on the escrow accounts is "frozen" for developers, but not for banks. "The minimum risk-free rate is equal to the key rate of the Central Bank and amounts to $7.75 \%$, more profitable instruments being also available. If to add 9-11\% on mortgages and credit interest of the developer, it becomes clear that the banks

Corresponding author: olga7771972@mail.ru 
can gain about $23 \%$ from the same house under construction. According to predictions of the experts, when the entire construction sector will be completely dependent on the banks, the latter can earn about 1.5 trillion rubles annually [19]. Meanwhile, for the developer, the project financing will cost almost twice as much as the funds of equity holders [1], since "all risks are associated not with the project financing mechanism itself, but with the size of the interest rate at which banks will lend to developers" [12].

In the present paper, we do not set the goal to study in detail the monetary policy of the Central Bank of the Russian Federation. However, we agree with Ershov [2], Katasonov [10], Glazyev [4], et al. that the business loan of the state is the main factor of maximizing investment in fixed assets as well as an advantage in global competition. The developed countries, issuers of reserve currencies, successfully employed this strategy, while the Central Bank of the Russian Federation stubbornly refuses to use it. In our opinion, the under-monetization of the economy (40\% of GDP compared to $100 \%$ or more in developed countries [4] and the high price of money hinders any good activity in the development of the domestic economy. The issues of the relationship between the established key rate, the lack of money in the state with ways to solve the problem of housing affordability were discussed in detail by us earlier $[5,6]$.

\section{Problem Statement}

The arrangement for using the escrow accounts established by Federal Law 214, January 1, 2019, formally prohibited construction companies to directly accept funds from equity holders. However, "from more than 4 thousand domestic construction companies 275 ones have escrow accounts" [15]. As, according to O.A. Mishchenko and V.I. Privalov, such a rate of opening accounts can lead an imbalance in the market and decrease the number of objects put into operation [15]. At the same time, the number of banks allowed to open escrow accounts and support projects amounted to 95 by June 1, 2019.

Solution of equity holder problems with the help of the project financing resembles a guillotine in the case of a headache: the interest rates cut off most small and medium-sized enterprises from the construction industry like a knife. We are talking about a radical change in the "landscape of the construction industry", when small companies will completely leave the market that results in "freezing" of the started housing construction projects [15]. "In the country as a whole, according to experts, it takes about 1 trillion rubles to finance new construction projects that do not fall under the old scheme of financing" [8]. This increases the leverage of the construction industry almost by 3 times and enhances the financial risks of the remaining companies.

The optimists of the project financing usually make the following arguments:

- only finished apartments will be presented on the market;
- risk of an increase in construction time will be minimized (its increase is absolutely unprofitable for the developer in new conditions);

- difference in the cost of housing at the excavation stage and finished housing will be reduced to almost zero;

- all risks are distributed between the developer and the bank, while the state and buyers do not risk at all;

- speculative factor of real estate purchase is neutralized;

- and, finally, there will be no significant increase or decrease in property prices [13].

Indeed, registration of ownership and actual implementation will be carried out only after the object is put into operation. However, nothing prevents the developer to initiate the accumulation of money in escrow accounts from the start of construction, manipulating the price per square meter of future housing. Therefore, the difference in the cost of housing at different stages of construction will not be zero at all. As a result, the speculative factor in the acquisition of real estate remains challenging.

The construction time can increase up to 6 months and even longer under circumstances beyond the control of the developer. Noteworthy, potential buyers do not have any more leverage in this case. All leverages have been given to the banks: their sanctions, one way or another, will force construction organizations to take it out on the consumers. Therefore, the last argument of the optimists sounds especially naïve. The reduction in the number of developers, monopolization of the housing market, a decrease in housing supply, high interest rates (the promise to reduce them to $8 \%$ by 2024 [16] is simply a mockery) inevitably increase prices per square meter of new housing. The dispute can only be about how much will raise the prices.

As for the risks, if a bank goes bankrupt, they will inevitably come upon the housing buyers and, ultimately, on the state, when the latter insures escrow accounts for up to 10 million rubles (Article 12.2 of the Federal Law of 23.12.2003 N 177-FZ, revised on 28.11.2018, "On insurance of deposits in banks of the Russian Federation" (as amended and supplemented, entered into force on 01.01.2019). "Let us note that the risks of developers are covered not by the deposit insurance system, but by escrow accounts." [18]

We are deeply convinced that banks, as intermediaries, should not make money on providing citizens with a vital benefit, a roof over their heads. The obligation to provide citizens with housing is spelled out in the Constitution of the Russian Federation.

\section{Research Questions}

\subsection{Methods for managing the working capital of a developer company in terms of project financing}

These issues and problems of the project financing are actively discussed in scientific and public circles. We 
would like to pose another task that escapes everyone's attention: how will building organizations provide the urgent need for working capital during the construction period? In the strict framework of the new legislation, is there a choice to optimize the ratio of funding sources for working capital and a classic compromise between a sufficient level of profitability and the risk of a shortage of the working capital $\mathrm{s}$, which entails a loss of solvency?

At first glance, there is no room for maneuver. The entire volume of working capital becomes credit for the entire construction period (minus the initial amount of the developer's own funds). However, the regulatory framework for the project financing of housing construction in Russia links the cost of funding sources for working capital with "conditional sales". We have proposed the term "conditional sales" to denote the accumulation of funds in escrow accounts.

In the present paper, we have analyzed the following possible approaches to crediting the need for working capital during the construction process: (i) the credit line is fully used at the beginning of the construction period; (ii) the credit line is used evenly during the construction period; (iii) the credit line is used as needed in the construction process. The first approach is strongly recommended by banks, since at the moment their software is not ready to use another credit line. Construction organizations are more accustomed to employ the working capital as production needs. The even application of the credit line during the construction period, from our point of view, is a compromise between two opposite positions (bank and construction organization). The weighted average interest rate on the credit line depends on the amount of money on escrow accounts, for example, as presented by JSC DOM.RF, founded by the Government of the Russian Federation. In the absence of money on escrow accounts, the rate is $12 \%$. When the escrow account reaches half of the credit line, the rate is $9 \%$. In case of the amount of money on escrow accounts coincides with the size of the credit line, the interest rate will be $6 \%$, and can be reduced to $3 \%$ if the amount of money in escrow accounts exceeds the amount of the credit line 1.5 times.

Consequently, the availability of working capital and, first of all, the costs of servicing the source of their financing (credits from banks holding escrow accounts) will depend on the rate of money accumulation by future home buyers, that is, on the choice of a sales strategy. Both this choice and its marketing support completely depend on the developer.

As a result, 4 possible strategies for "conditional sales" of future apartments can be proposed.

Strategy I comprises active sales of apartments at the beginning of construction. Due to the accumulation of money on escrow accounts, the interest rate may decrease.

Strategy II consists of active sales of apartments in the middle of construction. In the initial period, money on escrow accounts are close to zero and the interest rate may decrease only at the end of the construction period.

Strategy III involves active sales of apartments at the end of construction. In the initial and middle periods, money on escrow accounts are close to zero and the interest rate does not change during the entire construction period.

Strategy IV is based on active sales during the entire construction period. It is possible to reduce the credit interest rate by several times due to the accumulation of money on escrow accounts.

\subsection{Model for assessing the effect of the housing "conditional sales" strategy on the key subjects of the construction project financing}

The interests of the economic subjects of housing construction are different. When modeling, we considered the interest of the major actors: construction organization (developer), bank, population (consumers).

Table 1 summarizes the key indicators that are relevant to the application of project financing methods and depend on the choice of a sales strategy and accumulation on escrow accounts.

Legend:

$\mathrm{S}$ is the area of the construction object;

$\mathrm{n}$ is the number of periods (quarters);

$\mathrm{Q}_{\mathrm{t}}$ is the quantity of conditionally sold square meters in $\mathrm{n}$-period (quarter) $\mathrm{t}=\overline{1, \mathrm{n}}$;

$\mathrm{P}_{\mathrm{t}}$ is the price in $\mathrm{t}$ period (quarter);

$\mathrm{C}_{\mathrm{t}}$ is the sum of costs for construction of the object in $\mathrm{t}$-period;

NWC is net working capital;

$\mathrm{K}$ is the credit line (total amount of credits);

$3_{t}$ is the credit for interest charge in n-period;

$r_{t}$ is the bank's interest rate in the n-period;

$\ni_{t}$ is the amount of funds on escrow accounts in the $t$ -period.

ROE is Return on Equity, \%;

$\mathrm{Ra}$ is return on assets earnings before interest and taxes (EBIT)), \%;

$\mathrm{T}$ is the adjusted profit tax rate, units;

(1-T) is the tax corrector, net income / income before taxes;

$\mathrm{Kd}$ is the estimated tax rate for borrowed capital, «debt price», \%;

$\mathrm{L}$ is the borrowed capital, rubles;

$\mathrm{E}$ is the average of owned capital, rubles;

$\mathrm{L} / \mathrm{E}$ is the leverage;

$B_{j}$ is the income from conditionally sold square meters when implementing the $\mathrm{j}$ sales

$\mathrm{C}$ is the construction cost

$\Pi B_{i j}$ is the interest payment to the bank for the $\mathrm{i}$ type of crediting and $\mathrm{j}$ sales strategy.

The main interests of the population in the framework of housing construction are:

1) a reasonable ratio between the cost and quality of housing;

2) the ability to purchase housing in accordance with income;

3) minimal risks related to purchasing a new housing.

Most of the above interests have not been satisfied at the moment, since other economic actors involved in the housing construction process do not fully take into account the interests of the population. 
Table 1. Formalization of key indicators of the subjects of the project financing

\begin{tabular}{|c|c|}
\hline $\begin{array}{c}\text { Subjects and } \\
\text { indicators }\end{array}$ & Formula \\
\hline \multicolumn{2}{|r|}{ Developer: } \\
\hline Sales profit & $\begin{array}{c}\Pi \mathrm{H}_{i j}=B_{j}-C-\Pi \mathrm{\Pi B}_{i j} \\
i=\overline{1, m}, j=\overline{1, l} \\
B_{j}=\sum_{t=1}^{n} P_{t} \cdot Q_{t} ; \mathrm{C}=\sum_{t=1}^{n} \mathrm{C}_{t}\end{array}$ \\
\hline $\begin{array}{l}\text { Effect of } \\
\text { financial } \\
\text { leverage }\end{array}$ & $E F L=(1-T) \cdot\left(R_{a}-K_{d}\right) \cdot \frac{L}{E}$ \\
\hline Return on equity & $R O E=(1-T) R_{a}+E F L$, \\
\hline \multicolumn{2}{|r|}{ Bank: } \\
\hline $\begin{array}{l}\text { Interest income } \\
\text { from crediting } \\
\text { the developer }\end{array}$ & $\begin{array}{l}\qquad \Pi_{i j}=\sum_{t=1}^{n} 3_{t} \cdot r_{t} . \\
\text { The bank sets the interest rate depending on } \\
\text { the amount of money in escrow accounts: } \\
r_{t}= \begin{cases}r_{1}, & \text { at } \exists_{t}<\propto_{1} \kappa \\
r_{2}, & \text { at } \propto_{1} \kappa \leq \ni_{t}<\propto_{2} \kappa \\
r_{3}, & \text { at } \propto_{2} \kappa \leq \ni_{t}<\propto_{3} \kappa \\
r_{4}, & \text { at } \ni_{t} \geq \propto_{4} \kappa\end{cases} \end{array}$ \\
\hline \multicolumn{2}{|r|}{ Consumers: } \\
\hline $\begin{array}{c}\text { Increase of cost } \\
\text { of } 1 \mathrm{~m}^{2}\end{array}$ & $\mathrm{y} C_{i j}=\frac{\mathrm{nB}_{i j}}{S}$ \\
\hline
\end{tabular}

Compiled by the authors

\section{Purpose of the Study}

The purpose of this work is to offer tools that allow construction companies to expand their supply on the housing market through the rational use of their own and borrowed resources via the project financing with the escrow accounts.

\section{Research Methods}

The study is based on the method of economic and mathematical modeling, which includes several stages. The first stage comprises formulation of the economic problem and its qualitative analysis through understanding the available information on the topic under consideration.

The second stage involves the construction of a mathematical model via formalization of the economic relations of the problem in the form of specific mathematical dependencies and relationships.

The next stages relate to the mathematical analysis of the model and the preparation of the initial information to clarify generality of the model and to process information obtained from management accounting data of the developer.

At the stage of numerical solution, we have proposed an algorithm for the numerical solution of the problem, developed a software product, and calculated significant amounts of information.

The final stage includes the analysis of the numerical results and their application to reveal specific quantitative factors that influence economic processes. Also, the consequences of changes in the conditions of the development of economic subjects have been evaluated.

\section{Findings}

The proposed model has been tested by the example of activity of "Instroytech" company. The project envisages the construction of four residential buildings, including three 13-storey houses and one 10-storey house with 368 apartments of a total area of more than 24 thousand $\mathrm{m} 2$. The options of the strategy for selling apartments have been calculated assuming that a non-revolving credit line is used. We have assessed the amount of funds on escrow accounts on a quarterly basis for four sales strategies:

I - at the beginning of construction,

II - in the middle of construction,

III - at the end of construction,

IV - uniform sales throughout the construction period.

The average cost of construction of $1 \mathrm{~m} 2$ in the Irkutsk region is 51.900 rubles. In the initial period of construction, the selling price of $1 \mathrm{~m}^{2}$ is 54.000 rubles. This price increases quarterly by $2 \%$. The construction is carried out at the expense of own and borrowed funds. The need for working capital in each quarter is calculated by the authors as a percentage of the expenditures for the implementation of the project according to the data "UniverStroy" company (Table 2). As seen from Table 2, that the greatest need for financing falls on the middle of construction.

Table 2. The quarterly need for funds of the construction company, expressed as a percentage of the project cost.

\begin{tabular}{|c|c|c|c|c|c|c|c|c|c|}
\hline Quarter & 1 & 2 & 3 & 4 & 5 & 6 & 7 & 8 & 9 \\
\hline Percentage of the project cost & 9.69 & 11.57 & 14.95 & 11.07 & 13.38 & 13.01 & 13.33 & 3.32 & 3.94 \\
\hline
\end{tabular}

Source: calculated by the authors using the data of «UniverStroy» company

The amount of the developer's own funds should be at least $10 \%$ of the project cost, as stated in Federal Law 214 "On shared construction ...". When calculating, we used the size of the own funds at the level of $10 \%$ of the project cost (90\% of borrowed funds), since in the case of shared construction, construction organizations have borrowed this sum from the population [15]. In our calculations, we employed the values $\propto \_1=1 / 2, \propto \_2=3 / 4$, $\propto \_3=1, \llbracket \propto 2 \_4=11 / 2$ and r_1=12, r_2 =9, r_3=6, r_4 $=3$.

\subsection{From the perspective of a construction organization}

Profit of a construction company before taxes for various sale strategies is presented in Table 3 (the value that is best for a construction company is highlighted in bold).

For a developer, the highest profit is provided with equal crediting during construction and active sales of 
apartments at the end of construction. With the same type of crediting and various strategies for sales of apartments, the difference between the highest and the lowest profit before taxes reaches 127.451.400 rubles.
If to compare the best strategy of the project financing with a similar strategy in shared construction, then the construction organization loses up to $41 \%$ of profit.

Table 3. Profit of a construction company before taxes for various sale strategies using borrowed funds in the amount of $90 \%$ of the project cost

\begin{tabular}{|c|c|c|c|c|}
\hline $\begin{array}{ll}\text { Type of crediting } & \text { Sale strategy } \\
\end{array}$ & $\mathbf{I}$ & II & III & IV \\
\hline At the beginning of construction & -41183227 & -39120666 & -21541367 & -63307916 \\
\hline Evenly during the construction period & 29689799 & 88509739 & 157141199 & 79638137 \\
\hline As production needs & 29184520 & 91842385 & 125102807 & 72290865 \\
\hline
\end{tabular}

Source: calculated by the authors

\subsection{From the perspective of the bank}

The interest that the bank will receive from crediting in the amount of $90 \%$ of the project cost for the entire construction period is presented in Table 4 (the value that is the best for the bank is given in bold).
Table 4 shows that for a bank it is more profitable to grant a credit at the beginning of construction and fill escrow accounts at the end of construction. The data in Table 3, on the one hand, demonstrate the bank's income, and on the other hand, display how much money a construction company loses with the transition from shared construction to the project financing. The interest in the amount of 297.804 .276 rubles is $23.63 \%$ of the construction cost!

Table 4. Profit of a construction company before taxes for various sale strategies using borrowed funds in the amount of $90 \%$ of the project cost

\begin{tabular}{|c|c|c|c|c|}
\hline $\begin{array}{l}\text { Filling escrow accounts } \\
\text { Type of crediting }\end{array}$ & $\mathbf{I}$ & II & III & IV \\
\hline At the beginning of construction & 119121710 & 212717340 & 297804276 & 238243421 \\
\hline Evenly during the construction period & 47648684 & 85086936 & 119121710 & 95297368 \\
\hline As production needs & 50282269 & 86010902 & 155416715 & 106901253 \\
\hline
\end{tabular}

Source: calculated by the authors

\subsection{From the perspective of the consumer}

The construction company will include the interest for the use of borrowed funds in the cost of each square meter that will effect on the cost of housing for the consumers. The increase in the cost of $1 \mathrm{~m}^{2}$ for various types of crediting and the time of money transfer to the escrow account ("conditional purchase") are presented in Table 5.

Table 5. Increase in the cost of $1 \mathrm{~m}^{2}$ with various types of crediting and the time of transfer to escrow accounts when crediting a construction organization in the amount of $90 \%$ of the project cost

\begin{tabular}{|l|c|l|c|c|}
\hline $\begin{array}{r}\text { Filling escrow } \\
\text { accounts }\end{array}$ & I & II & III & IV \\
Type of crediting & 4905 & 8758 & 12261 & 9809 \\
\hline $\begin{array}{l}\text { At the beginning of } \\
\text { construction }\end{array}$ & 1962 & 3503 & 4905 & 3924 \\
\hline $\begin{array}{l}\text { Evenly during the } \\
\text { construction period }\end{array}$ & 2070 & 3541 & 6399 & 4401 \\
\hline As production needs & &
\end{tabular}

Source: calculated by the authors

The data of Table 5 show, on the one hand, the increase in cost of $1 \mathrm{~m} 2$ for a construction organization. On the other hand, Table 5 demonstrates how this fact will affect the price for the consumer, in whose interests such an increase is undesirable. In Table 6, the percentage of cost increase that the developer includes in the future housing price, is presented.
Table 6. I Increase in the cost of $1 \mathrm{~m}^{2}$ with various types of lending and the time to transfer money to escrow accounts, \%

\begin{tabular}{|l|c|c|c|c|}
\hline $\begin{array}{r}\text { Filling escrow } \\
\text { accounts }\end{array}$ & I & II & III & IV \\
$\begin{array}{l}\text { Type } \\
\text { of crediting }\end{array}$ & 9.5 & 16.9 & 23.6 & 18.9 \\
\hline $\begin{array}{l}\text { At the beginning of } \\
\text { construction }\end{array}$ & 3.8 & 6.7 & 9.5 & 7.6 \\
\hline $\begin{array}{l}\text { Evenly during the } \\
\text { construction period }\end{array}$ & 4.0 & 6.8 & 12.3 & 8.5 \\
\hline As production needs & & & \\
\hline
\end{tabular}

Source: calculated by the authors

Our calculations prove that in case of project financing of housing construction, the credit load for a construction organization significantly affects the increase in the cost of $1 \mathrm{~m}^{2}$ for the consumer, on average. In all options, this increase is about $10 \%$, but banks will certainly seek the most profitable options for themselves that leads to the rise in housing prices by $16-23 \%$.

\section{Conclusion}

With the help of the project financing in housing construction, our state intends to solve the problem of providing the population with housing [17]. The interaction of subjects of the project financing is full of contradictions. Risks of the developer risks are covered by filling escrow accounts. It is beneficial for the bank to 
cover the need for the developer's working capital in full at the initial stage, thus deforming the developer's balance sheets, threading its financial stability, and increasing the financial expenses. As in the case of shared construction, the consumer should immobilize money on escrow accounts at the excavation stage, losing the profit from the possible use of the accumulated financial resources in order to reduce the price per square meter. It would be preferable for the developer to sell all apartments after the completion of the project at the maximum price, but in order to reduce interest rates on the credit the developer should replenish escrow accounts with the only available way, i.e. to raise the price of housing. If not to employ the administrative resource to oblige the bank to credit the developer depending on the production need, lowering the interest with the replenishment of escrow accounts, then no compromise will be reached. Consequently, the project financing will trigger a pathological process: massive bankruptcy of developers, freezing of numerous housing projects, decrease in supply volumes, and the growth of in prices for the ready objects in 2-3 years due to developer credits. Ultimately, this growth will be attributed to the cost of construction and will significantly increase the selling prices of the "new housing" [14], according to our calculations, at least by $15-22 \%$.

The estimations of the effects of project financing of housing construction on the interests of its subjects (developer, bank and consumer) differ significantly. Despite the fact that economic actors interact with the aim of providing the population with affordable and high-quality housing, their positions are not equal. Consumers are the most deprived of rights. They cannot influence the price per square meter of housing under construction and bank credit rates. Meanwhile, the bank can agree with the developer to the prejudice of the consumer. Apparently, the problem can be solved via drastic changes in the monetary policy of the Central Bank of the Russian Federation and through state regulation of interest rates on mortgage and the developer credits within the framework of project financing to overcome lifelong financial slavery of most of the population in order to fulfill the basic living need, a need for a roof over the head.

\section{References}

1. E.A. Alekseeva. The advantages and disadvantages of the transition to project financing of housing construction. Topical issues of law, economics and management: collection of articles of the XIX International Scientific and Practical Conference (MCNS, Science and Education, Penza, 2019), pp. 231-233

2. M. Ershov. The 2008 Crisis: "A Moment of Truth" for the Global Economy and New Opportunities for Russia. Econ. issues, 12, 4-26 (2008). Retrieved from: https://doi.org/10.32609/0042-8736-2008-124-26
3. J. Gathergood, J. Weber (2017). Financial literacy, present bias and alternative mortgage products. J. of Bank. \& Fin., 78, 58-83

4. S.Yu. Glazyev. Leap into the future. Russia in new technological and world economic structures. Collection of the Izborsk club (Book World, Moscow, 2018)

5. O.V. Grushina. Theoretical and methodological comprehension of the main aspects of capital deficit in the Russian Federation as one of the obstacles to achieving affordable housing prices. J. Labour and social relations (2011). Retrieved from: http://www.e-rej.ru/Articles/2011/Grushina.pdf

6. O.V. Grushina. Strategy for ensuring the affordability of housing in the Russian Federation. (BSU Publ. House, Irkutsk, 2017)

7. R. Hilferding. Financial capital. The newest phase in the development of capitalism (State product., Moscow, 1924)

8. S. Ishkov. Temporary stress: how the introduction of escrow accounts will change the market (2019). Retrieved from: https://pro.rbc.ru/demo/5c73af629a7947ef6ae2a42c

9. H. Jialin, R. Zhao. Housing boom, real estate diversification, and capital structure: Evidence from China. Emerg. Mark. Rev., 32, 74-95 (2017)

10. V.Yu. Katasonov. About the interest on the loan, the court, the reckless. A textbook of modern problems of "monetary civilization" (Publ. House Res. Inst. of School Technol., Moscow, 2011)

11. H.L. Kim, N. Graeme. Real estate global beta and spillovers: An international study. Econ. Modell., 59, 297-313 (2016)

12. A.Yu. Kovalenko. Risks of transition from equity participation to project financing. Prospects for the development of science and education. Collection of scientific papers based on the materials of the international scientific and practical conference (2017), pp 65-67

13. I.A. Kharitonova, T.O. Pinchuk. The reason for the cancellation of equity financing of residential construction and the transition to project financing. ISTU Youth Bull., 8, 135-140 (Publ. of Irkutsk Nat. Res. Techn. Univ., Irkutsk, 2018)

14. A.N. Larionova. On the issue of premature abandonment of shared construction and transfer of housing construction to project financing. Constr., econ. and manag., 3(31), 4-11 (2018)

15. O.A. Mischenko, V.I. Privalov. Bank ecosystem as a mechanism to reduce the credit risk for project financing. Econ. of stable develop., 1(37), 52-56 (2019)

16. A. Petrov. Forecast of the Ministry of Finance for 8 $\%$ mortgages depends on the Central Bank rate (2018).

from: https://rueconomics.ru/354140-prognozminfina-po-8-ipoteke-zavisit-ot-stavki-cb 
17. N.N. Shelomenceva. To the problem of project financing in housing construction. Econ. of Constr., 6, 22-31 (2018)

18. A.N. Shulekin. Analysis of changes in legislation in the field of housing construction: the transition from shared construction to project financing. Siber. Finan. school, 4(129), 34-37 (2018)

19. L. Taejun. Growth, financial development, and housing booms. J. Econ. Modell. (2017)

20. A.A. Tsygankova, D.I. Koptelova, K.A. Bareshenkova. Residential construction project management during transition to project financing and digital technologies. Contemporary problems of project management in investment and construction sphere and environmental management. Proceedings of IX International Scientific and Practical Conference, devoted to the 112th anniversary of Plekhanov Russian University of Economics (Rus. Univ. of Econ. named after G.V. Plekhanov, Moscow, 2019), pp. 226-232

21. N.V. Voronina, V.V. Serova. Project financing as a new mechanism of financing household construction objects. Electr. Sci. publicat. "Scientific Notes of PNU”, 9(2), 55-60 (2018) 